\title{
THE INFLUENCE OF INFORMATION SHARING AND INFORMATION QUALITY TOWARD SUPPLY CHAIN INTEGRATION AND ENTERPRISE PERFORMANCE (Study of Shallot Farmers in East Java)
}

\author{
Roihatul Musyafi ${ }^{1 *}$, Hamidah Nayati Utami ${ }^{2}$, Arik Prasetya ${ }^{3}$ \\ ${ }^{1}$ Master Program of Business Administration, University of Brawijaya, Malang, Indonesia \\ ${ }^{2}$ Department of Business Administration, Faculty of Administrative Sciences, University of \\ Brawijaya, Malang, Indonesia
}

\begin{abstract}
Purpose - This research was conducted to study the effect of information sharing and information quality toward supply chain integration and farmer business performance.

Design/methodology/approach - The type of this research is quantitative explanatory research. The data used in this study are primary data obtained by questionnaire. The sampling method uses multistage proportional random sampling, sample obtained amount 200 farmers. Data analysis in this study uses path analysis method with SPSS 23.

Findings - The results of this research indicate that the quality of information is not significant to the integration of supply chain and farmer business performance. Information sharing has a positive and significant effect toward supply chain integration and farmer business performance, supply chain integration has a positive and significant effect toward farmer business performance.

Practical Implications - Increasing global business competition and efforts to shorten product life cycles are the two main factors that encourage businesses to change their focus from competitive competition to mutually beneficial relationships and cooperation to improve business performance.
\end{abstract}

Originality/value - The main objective of supply chain activities for business activities is a crucial element because with these activities the goods produced can reach the end consumers.

Keywords - Information Sharing, Information Quality, Supply Chain Integration, Enterprise Performance.

Vol. 28, No. 2 August 2020

(C) Centre for Indonesian Accounting and Management Research Postgraduate Program, Brawijaya University 


\section{INTRODUCTION}

Increasing global business competition and efforts to shorten product life cycles are the two main factors that encourage businesses to change their focus from competitive competition to mutually beneficial relationships and cooperation to improve business performance (Lambert and Cooper, 2000; Wisner and Keah, 2000). To stay focused on maintaining the intended strategy in the price control process so that it can still compete in the market, then every element involved in the supply chain must have a good and directed relationship. This can be done by creating good efficient proactive relationships between internal functions and external agents contained in supply chain networks (Qi et al., 2011; Narasimhan and Kim, 2002). Therefore, business actors must have good integration with suppliers and external customers in a supply chain that will have an impact on improving business performance (Frohlich and Westbrook, 2001; Zailani and Rajagopal, 2005).

Companies or organizations that have a supply chain orientation, make it possible to act and behave consistently with their supply chain management guidelines so as to create management practices that lead to strategic and tactical integration and coordination between companies. One of the activities that can encourage the occurrence of good supply chain management practices is an integrative supply chain which is a useful approach to improve various measures of corporate performance (Otchere, et al., 2013). Integration can be characterized by cooperation, collaboration, information sharing, trust, partnership and technology. A competitive business environment makes a supply chain relationship increasingly challenging for business actors and makes efforts to compete together in each of the supply chain elements involved.

An integrative supply chain is a strategic integration of both internal and external organizations (Flynn, et al., 2010) and measures the extent to which partners involved in the supply chain work together to obtain mutually beneficial results (O'Leary-Kelly and Flores, 2002 ) Integration that occurs in the supply chain model in agriculture refers to practices in which farmers as producers and consumers directly relate to trading partners (traders or middlemen) and suppliers to integrate cooperative strategies, processes, practices and behaviors to produce harmonious and consistent to meet end customer needs. According to (Zhao et al., 2008a, 2008b; Flynn et al., 2010) Practice and cooperation processes carried out in the supply chain process become a very important part of supply chain integration activities.

The main purpose of integration in the supply chain is to get the movement of products, information, money and decisions through business coordination to customers effectively and efficiently at low cost without delay (Frohlich and Westbrook, 2001; Wong, et al., 2011). If the main goal in the practice of supply chain integration does not materialize, problems will arise that cause losses to various parties involved and have an impact on business performance. The problems of integration that will arise in the field of agricultural business include the emergence of high costs in the production process and the length of the distribution chain to the final consumer, which causes an imbalance in determining the initial price of the product from the farmer to the final consumer. This is supported by the opinion (Chao et al., 2006) that looking at the cycle of problems that arise in agriculture is the uncertain time of specific agricultural product growth and vulnerability to seasons due to environmental conditions plus scope for opportunistic

Vol. 28, No. 2 August 2020

(C) Centre for Indonesian Accounting and Management Research Postgraduate Program, Brawijaya University 
behavior (eg pesticide use, herbicides and fertilizer) which causes additional production costs.

The main objective of supply chain activities for business activities is a crucial element because with these activities the goods produced can reach the end consumers. This is because the supply chain can provide added value for every business actor involved in it. If the supply chain practices run efficiently, the movement of products from producers to consumers will be pursued at the cheapest cost by minimizing the extension of the distribution chain. This can be achieved by identifying supply chain practices that are key activities in the success and importance of supply chains in business activities and avoiding the efficiency of the distribution chain.

Among the many supply chain practices mentioned in supply chain management, both of information sharing and information quality are very important practices in the continuity of coordination and cooperation between each party so that good integration can have an impact on business performance and can be a measuring tool whether business performance is generated by good or bad. Effective supply chain management enables businesses or business organizations to coordinate and integrate various flows (physical, financial and information) in their supply chain systems (Lee, 2000). In supply chain management, strong integration is needed to establish relations from upstream to downstream with the elements involved. This can be seen by analyzing how supply chain management practices can influence business performance through effective development of supply chain management practices that focus on information sharing and information quality and effective supply chain integration (Kim, 2006).

Information sharing refers to the extent to which information is communicated effectively among members of the supply chain (Li et al., 2006; Mentzer et al., 2001). Supply chain members who share information regularly and can often work collaboratively as a single entity ( Stein and Sweat, 1998) means that, when information sharing goes well and correctly, there will be no misinterpretation of perceptions and allows to accelerate accurate decision making. This can be seen as a source of competitive advantage (Moberg et al., 2002). Information sharing is not only important in the manufacturing industry but also in the agricultural sector. In (Chao et al., 2006) it was found that improving quality in information sharing in the agricultural industry is very important to increase trust among members of the supply chain and to ensure the effectiveness of its marketing strategy.In measuring the accuracy of an Information sharing in the supply chain, it is inseparable how we measure the quality of the information. Many studies have discussed the importance of Information quality in supply chain management, among others (Rabren, 2010; and Omar, 2010; Li 2006; Miller 2005; Raghunathan, 1999; Monczka 1998; Gustin 1995 ;), explaining that Information quality between customers and suppliers can be used as an indicator to improve performance. Another study (Holmberg, 2000; Forslund and Jonsson, 2007) states that Information quality is a quality obtained in the exchange of information. These factors include the level of accuracy, timeliness, credibility and adequacy of information exchanged. Information quality in supply chain management (SCM) has gained importance recently because of its ability to reduce costs and increase responsiveness in the supply chain. The more quality information is shared, the more appropriate decisions are made by managers or related elements, and the more effective the supply chain management (Raisinghani 
and Meade, 2005). To improve business performance, managers need quality information to make tactical or strategic operational decisions.

In the agricultural industry supply chain management, especially shallot, has certain characteristics because it is influenced by the production, bulky, perishable and quality systems which decrease continuously while the demand for shallots occurs all the time. In the agricultural industry the weather or season greatly affects production because they have a special time of the planting season so that the production process cannot be done all the time. Shallot planting season is generally carried out during the dry season, while in the rainy season farmers rarely grow shallots (Purmiyati 2002; Winarso 2003; Mayrowani and Darwis 2009) because they are faced with high disease attacks (Purba and Astuti 2013). The influence of the season does not only cause fluctuating production, but also results in price fluctuations (Irawan 2007; Susanawati et al. 2015). The nature of perishable products, but consumed continuously throughout the year causes very rapid price changes (Ariningsih and Tentamia 2004; Asmara and Ardhiani 2010; Sukesi et al. 2014). On the other hand, the results of research by Nuraeni et al. (2015) shows that there is no integration between the producer market and the wholesale and retail markets in the short term. This shows that the supply chain system in the shallot farming industry has not been efficient.

The long supply chain in shallot commodities triggers how information flows and information quality play a role in integrating into all the elements involved and resulting in an increase in business performance in it. In line with the article in Forbes which states that supply chains are very important in agriculture not only in the type of manufacturing business because agricultural products have a shorter durability than manufacturing products so that management of the supply chain becomes very important.

Shallot is one of the strategic horticultural commodities considering its function as a staple food in Indonesia. Shallot (Allium ascalonicum L) develops and cultivates farmers from the lowlands to the highlands. The cultivation system is the development of traditional subsystems to intensive and market-oriented ways of cultivation. Although shallot production tends to increase every year, domestic production to date has not been able to meet all the needs of shallots in Indonesia. This can result in an increase in the price of shallots in the domestic market. Such conditions can encourage inflation given that one of the causes of inflation, especially food commodities, is that prices have increased dramatically due to lack of supply (Prastowo et al., 2008).

From the description of the above problems, the researcher is interested in explaining and knowing how supply chain management practices, namely information sharing, information quality and integrative supply chains can influence business performance in practice for farmers in the four largest shallot producing cities in East Java, Nganjuk, Probolinggo, Kediri and Malang. In addition to being the largest producer of shallots, they have an organizational body called GAPOKTAN (Gabungan Kelompok Tani / Combination of Farmer Groups) in each district and can be called a business organization that can be measured in the level of business performance. So that research is carried out with the title "Effects of Information Sharing and Information Quality toward Integrative Supply Chains and Their Impacts on Performance (Study on Shallot Commodities)".

\section{LITERATURE REVIEW}

Vol. 28, No. 2 August 2020

(C) Centre for Indonesian Accounting and Management Research Postgraduate Program, Brawijaya University 


\section{Information Sharing}

Information sharing is the intensity and capacity of companies in their interactions to share information with partners in relation to joint business strategies. According to (Lie, at, al 2010). information must have several characteristics in order to be useful in making supply chain decisions, namely the quality and quantity possessed by that information.

\section{Information Quality}

Forslund and Jonsson (2007) The quality of information depends on three things or includes elements, namely information must be accurate, timely and relevant (relevance) or reliable. Measuring this variable uses these indicators, namely:

\section{Integrative Supply Chain}

An integrative supply chain is the extent to which all activities in an organization and the activities of suppliers, customers and other members of the supply chain are integrated (Flynn, et al., 2010). This variable is measured by two indicators according to Narasiman and Kim, (2002); Stanley and Wisner, (2001); Huo, et al. (2014); Sezen (2010), namely: (monitoring process), (jointy improve production).

\section{Business Performance}

Business performance is defined as an increase in business performance in the last three years (Orsi, et al., 2010) by looking at product quantity, product quality, and increasing profit.

\section{CONCEPTS AND METHODS}

This type of research is explanatory research with a quantitative approach. Ecplanatory research is a type of research that emphasizes causality or causality between two or more variables that influence each other. The framework of thinking flow in this study was built based on existing phenomena as well as problems and research objectives that have been described at the outset. This study aims to describe or explain and test the effect of Information Sharing and Information Quality which is part of the practice of supply chain management on integrative supply chains and business performance of shallot farmers. This research was conducted on 200 farmers in four of the largest shallot producing districts in East Java Province, namely, Nganjuk Regency, Kediri Regency, Malang Regency and Probolinggo Regency. The sampling method in this study used multistage proportional random sampling. Multistage is sampling in two stages or more (Nazir, 2014: 243). This study uses multistage because researchers cannot identify population easily and the population is very large. The following conceptual framework of this research is as follows:

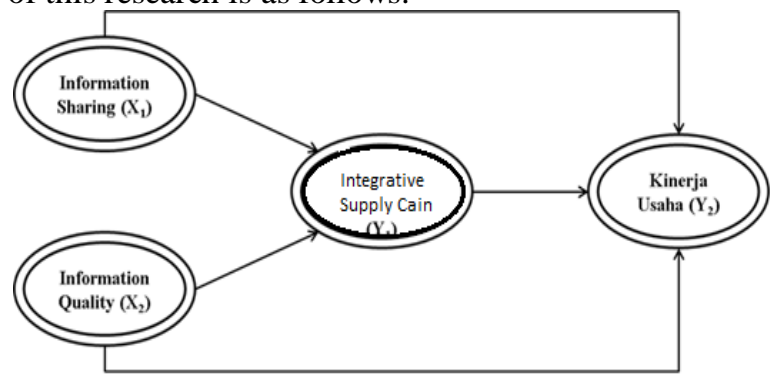

Vol. 28, No. 2 August 2020 
106 The Influence Of Information Sharing And Information. . . . .

Vol. 28, No. 2 August 2020

(C) Centre for Indonesian Accounting and Management Research Postgraduate Program, Brawijaya University 


\section{RESULTS AND DISCUSSION \\ Validity And Reliability Test Results}

Test the validity and reliability on do to see the validity of the instruments used. Path analysis test results Validity is measured from $r \geq 0.30$ basis decision making is said to be valid if the coefficient value is more than 0.3 . The basis for decision making is whether a measurement is reliable or not. If the alpha crobach value is greater than 0.6 , it can be called reliable.

Table 2 Reliability Test Results

\begin{tabular}{|c|c|c|c|}
\hline No & Variable & Alpha & Variabel \\
\hline 1. & $\begin{array}{c}\text { Information Sharing } \\
\left(\mathrm{X}_{1}\right)\end{array}$ & 0,620 & Reliabel \\
\hline 2. & $\begin{array}{c}\text { Information Quality } \\
\left(\mathrm{x}_{2}\right)\end{array}$ & 0,765 & Reliabel \\
\hline 3. & $\begin{array}{c}\text { Integrative Supply } \\
\text { Chain }\left(\mathrm{Y}_{1}\right)\end{array}$ & 0,614 & Reliabel \\
\hline 4. & $\begin{array}{c}\text { Business } \\
\text { Performance }\left(\mathrm{Y}_{2}\right)\end{array}$ & 0,886 & Reliabel \\
\hline
\end{tabular}

Table 1 Validity test results

\begin{tabular}{|c|c|c|c|c|c|}
\hline No & Variable & Indicator & No.Item & $\begin{array}{c}\text { correlation } \\
(\mathbf{r})\end{array}$ & Note \\
\hline \multirow{4}{*}{1.} & \multirow{4}{*}{$\begin{array}{l}\text { Information } \\
\text { Sharing }\left(\mathrm{X}_{1}\right)\end{array}$} & \multirow{2}{*}{ Quality } & Item 1 & 0,681 & Valid \\
\hline & & & Item 2 & 0,747 & Valid \\
\hline & & \multirow{2}{*}{ Quantity } & Item 3 & 0,637 & Valid \\
\hline & & & Item 4 & 0,689 & Valid \\
\hline \multirow{5}{*}{2.} & \multirow{5}{*}{$\begin{array}{l}\text { Information } \\
\text { Quality }\left(\mathrm{x}_{2}\right)\end{array}$} & \multirow{2}{*}{$\begin{array}{l}\text { Information } \\
\text { Exchange } \\
\text { Place }\end{array}$} & Item 1 & 0,560 & Valid \\
\hline & & & Item 2 & 0,451 & Valid \\
\hline & & Accurate & Item 3 & 0,714 & Valid \\
\hline & & On time & Item 4 & 0,781 & Valid \\
\hline & & Reliable & Item 5 & 0,765 & Valid \\
\hline \multirow{4}{*}{3} & \multirow{4}{*}{$\begin{array}{c}\text { Rantai Pasok } \\
\text { Integratif } \\
\left(\mathrm{Y}_{1}\right)\end{array}$} & \multirow{2}{*}{$\begin{array}{c}\text { Monitoring } \\
\text { Process }\end{array}$} & Item 1 & 0,727 & Valid \\
\hline & & & Item 2 & 0,781 & Valid \\
\hline & & \multirow{2}{*}{$\begin{array}{c}\text { Jointly } \\
\text { Improve } \\
\text { Production }\end{array}$} & Item 3 & 0,607 & Valid \\
\hline & & & Item 4 & 0,593 & Valid \\
\hline \multirow{6}{*}{4.} & \multirow{6}{*}{$\begin{array}{c}\text { Kinerja } \\
\text { Usaha }\left(\mathrm{Y}_{2}\right)\end{array}$} & $\begin{array}{c}\text { Production } \\
\text { Quantity }\end{array}$ & Item 1 & 0,763 & Valid \\
\hline & & \multirow{5}{*}{$\begin{array}{l}\text { Quality of } \\
\text { Production }\end{array}$} & Item 2 & 0,783 & Valid \\
\hline & & & Item 3 & 0,847 & Valid \\
\hline & & & Item 4 & 0,724 & Valid \\
\hline & & & Item 5 & 0,682 & Valid \\
\hline & & & Item 6 & 0,757 & Valid \\
\hline
\end{tabular}




\begin{tabular}{|l|c|c|c|c|c|}
\hline & & $\begin{array}{c}\text { The } \\
\text { advantage }\end{array}$ & Item 7 & 0,723 & Valid \\
\cline { 4 - 6 } & & $\begin{array}{c}\text { Generated } \\
\text { (Profit) }\end{array}$ & Item 8 & 0,702 & Valid \\
\hline
\end{tabular}

\section{Path Analysis Test Results}

There are 7 hypotheses tested, the influence of Information Sharing variables toward Integrative Supply Chains, Information Sharing toward Business Performance, the effect of Information Quality variables toward Integrative Supply Chains, the Effect of Information Quality toward Business Performance and the Effect of Integrative Supply Chains toward Business Performance and Influence indirect Information Sharing and Information Quality toward Business Performance through Integrative Supply Chains.

Table 3. Path Analysis Test Results Direct and Indirect Effects

\begin{tabular}{|c|c|c|c|c|}
\hline $\mathrm{H}$ & $\mathrm{B}$ & $\begin{array}{c}\mathrm{T} \\
\text { Statistic }\end{array}$ & $\begin{array}{c}\mathrm{P} \\
\text { Value }\end{array}$ & Note \\
\hline $\mathrm{X} 1-\mathrm{Y} 1$ & 0,383 & 5,080 & 0,000 & Significant \\
\hline $\mathrm{X} 2-\mathrm{Y} 2$ & 0,023 & 0,308 & 0,758 & Insignificant \\
\hline $\mathrm{X} 1-\mathrm{Y} 2$ & 0,139 & 1,996 & 0,040 & Significant \\
\hline $\mathrm{X} 2-\mathrm{Y} 2$ & 0,075 & 1,145 & 0,253 & Insignificant \\
\hline $\mathrm{Y} 1-\mathrm{Y} 2$ & 0,557 & 9,013 & 0,000 & Significant \\
\hline $\begin{array}{c}\mathrm{X} 1-\mathrm{Y} 1- \\
\mathrm{Y} 2\end{array}$ & 0,426 & 4,419 & 0,000 & Significant \\
\hline $\begin{array}{c}\mathrm{X} 2-\mathrm{Y} 1- \\
\mathrm{Y} 2\end{array}$ & 0,024 & 0,308 & 0,757 & Insignificant \\
\hline
\end{tabular}

Source; Primary data processed 2019

Table 3 shows that the Information Sharing variable $\left(\mathrm{X}_{1}\right)$ directly has a significant effect toward integrative supply chain variables $\left(\mathrm{Y}_{1}\right)$ and toward Business performance variables $\left(\mathrm{Y}_{2}\right)$ while the indirect effects of Information Sharing $\left(\mathrm{X}_{1}\right)$ variables toward Business Performance $\left(\mathrm{Y}_{2}\right)$ through integrative supply chains $\left(\mathrm{Y}_{1}\right)$ shows significant results too. The Information Quality $\left(\mathrm{X}_{2}\right)$ variable directly shows insignificant effect toward integrative supply chain variables $\left(\mathrm{Y}_{1}\right)$ and business performance variables $\left(\mathrm{Y}_{2}\right)$ and results from the indirect effect of Information Quality $\left(\mathrm{X}_{2}\right)$ variables on Business Performance $\left(\mathrm{Y}_{2}\right)$ through integrative supply chains $\left.\mathrm{Y}_{1}\right)$ the result has insignificant effect.

The accuracy of the hypothesis model from this research data refers to the relationship of the coefficient of determination $\left(\mathrm{R}^{2}\right)$ in the two equations. The model results are as follows:

$$
\begin{aligned}
\mathrm{R}^{2} \text { model }=1-(1 & \left.-\mathrm{R}^{2}{ }_{1}\right)\left(1-\mathrm{R}^{2}{ }_{2}\right) \\
& =1-(1-0,158)(1-0,358) \\
& =1-(0,842)(0,642) \\
& =1-0,5405=0,4595 \text { or } 46 \%
\end{aligned}
$$

The results of the calculation of model accuracy of $46 \%$ explained that the contribution of the model to explain the structural relationship of the three variables studied was $46 \%$. While the remaining $54 \%$ is explained by other variables that are not 
in this research model. The image results from the path analysis equation of the path diagram below are as follows:

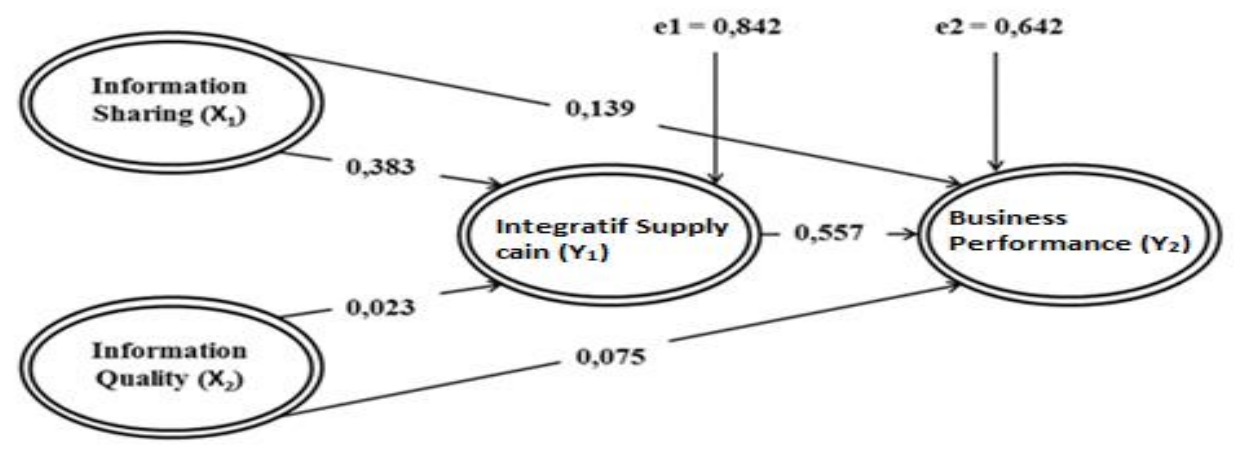

Figure 5.1 Path analisys diagram of Information Sharing, Information Quality, Integrative Supply Chain, and Business Performance

The diagram of the path analysis results in Figure 5.1 has the following equation:

Sub Structure I : Y1 = 0,383 X1 + 0,023 X2

Sub Structure II : Y2=0,139 X1 + 0,075 X2 + 0,557Y1

\section{The Effect of Information Sharing toward Integrative Supply Chains}

The results of path analysis prove that there is a positive and significant influence between Information Sharing $\left(\mathrm{X}_{1}\right)$ toward Integrative Supply Chains $\left(\mathrm{Y}_{1}\right)$. Obtained a beta coefficient of 0.363 means that the effect of Information Sharing toward Business Performance has a positive direction, with a tcount of 5.080 and a probability of $0.000 \mathrm{p}$ $<0.05)$, then the decision is $\mathrm{H} 1$ accepted and $\mathrm{H} 0$ rejected, which means that the higher Information sharing $\left(\mathrm{X}_{1}\right)$ will increase the Integrative Supply Chain $\left(\mathrm{Y}_{1}\right)$ and vice versa if the lower Information sharing $\left(\mathrm{X}_{1}\right)$ will reduce the Integrative Supply Chain $\left(\mathrm{Y}_{1}\right)$. These results reinforce the results of research conducted by (Sundram, et al., 2015) which examines information sharing variables can influence integrative supply chains.

The relationship pattern that occurs between shallot farmers and trading partners from Information Sharing activities spread across 4 (four) cities in East Java, namely Probolinggo, Nganjuk, Kediri and Malang is divided into two stages, namely information needed before the production period or pre- harvest and post-harvest information after production which includes the quality and quantity of information. Information Sharing activities carried out pre-harvest occur among fellow farmers and partners, information needed regarding agricultural production facilities and quality standards for farming methods that are coordinated through routine farmer group activities. This causes the requirement information by farmers for the production of shallots can be fulfilled so that the integration or relationship that exists between farmers and partners goes well. Furthermore, Information Sharing activities carried out by farmers and post-harvest trading partners include the first, information on market needs, where this related information is very important so that farmers are able to meet the needs of shallots on demand and are able to predict market conditions that occur. This is in line with opinion 
(Singh, 1996) To ensure that customer requirements in the supply chain can be fulfilled, it is important to manage the flow of information related to the movement of products (goods or services) to end customers). Second, the information requirement is related to the post-harvest / harvest supply chain process where it is expected to be able to see and adjust the prices or income of the farmers obtained and be able to balance pre-harvest production needs. Information Sharing activities are very important because they provide a mechanism for coordination and integration of processes or activities along the supply chain (Le, 2000; Ramayah and Omar, 2010). Effective product and service flows depend on information sharing among members of the supply chain (Le at al., 1997a).

\title{
The Effects of Information Sharing toward Business Performance
}

The results of path analysis prove that there is a significant positive influence between Information Sharing $\left(\mathrm{X}_{1}\right)$ toward Business Performance $\left(\mathrm{Y}_{2}\right)$. Obtained beta coefficient value of 0.139 means that the effect of Information Sharing $\left(\mathrm{X}_{1}\right)$ on Business Performance $\left(\mathrm{Y}_{2}\right)$ has a positive direction, with tcount of 1.139 and probability of 0.000 ( $\mathrm{p}<0.05$ ), then the decision is $\mathrm{H}_{1}$ accepted and $\mathrm{H}_{0}$ rejected, which means that the higher Information Sharing $\left(\mathrm{X}_{1}\right)$ will improve Business Performance $\left(\mathrm{Y}_{2}\right)$ and vice versa the lower the Information Sharing, the lower the Business Performance of farmers. This can be categorized that the effect of information sharing $\left(\mathrm{X}_{1}\right)$ toward business performance $\left(\mathrm{Y}_{2}\right)$ is quite good. These results indicate that the pattern of Information Sharing activities that are intertwined among fellow shallot farmers and trading partners influences the increase in farmer business performance. This supports the statement (Zhao et al, 2002) that companies or organizations that implement information sharing well are able to improve performance.

\section{The Effect of Information Quality toward Integrative Supply Chains}

The results of path analysis prove that there is a positive but not significant influence between Information Quality $\left(\mathrm{X}_{2}\right)$ toward Integrative Supply Chains $\left(\mathrm{Y}_{1}\right)$. Obtained a beta coefficient of 0.023 means that the effect of Information Quality $\left(\mathrm{X}_{2}\right)$ toward Integrative Supply Chains $\left(\mathrm{Y}_{1}\right)$ has a positive direction, with tcount of 0.308 and probability of $0.758(\mathrm{p}>0.05)$, then the decision is $\mathrm{H}_{0}$ accepted and $\mathrm{H}_{1}$ rejected , which means that Information Quality $\left(\mathrm{X}_{2}\right)$ has a positive but not significant effect toward Integrative Supply Chains $\left(\mathrm{Y}_{1}\right)$. The results of this study do not support the research conducted by Sundram, et al. (2015) who found a direct influence between Information Quality $\left(\mathrm{X}_{2}\right)$ toward Integrative Supply Chains $\left(\mathrm{Y}_{1}\right)$ which was positive and significant. This study also does not support the results of the Soo Wook Kim Research (2006) which shows that there is a significant relationship between the quality of information and the integrative supply chain.

In practice, Information Quality as one of the driving activities for good integration in the 4 largest shallot producing districts in East Java between farmers, trading partners and suppliers, each has a different level and pattern of accuracy, timeliness and reliability so that it does not support, thus causing Information Quality practices to not run well and the integration process does not work well between the elements involved in the supply chain. In this case, farmers are able to predict and handle how these pests can be resolved and eradicated before the process of sharing information by trading partners and suppliers is carried out, this is due to farmers being able to predict

\author{
Vol. 28, No. 2 August 2020 \\ (C) Centre for Indonesian Accounting and Management Research \\ Postgraduate Program, Brawijaya University
}


themselves how to deal with scattered pests using intuition and feeling due to many years of farming year. The process of strengthening the results of Information Quality does not have a significant effect on the Integrative Supply Chain.

\section{The Effect of Information quality toward Business Performance}

The path analysis results prove that there is a positive but not significant influence between Information Quality $\left(\mathrm{X}_{2}\right)$ toward Business Performance $\left(\mathrm{Y}_{2}\right)$ Obtained a beta coefficient of 0.075 means that the effect of Information Quality $\left(\mathrm{X}_{2}\right)$ toward Business Performance $\left(\mathrm{Y}_{2}\right)$ has a positive direction, with t count amounting to 1.145 and probability of $0.253(\mathrm{p}>0.05)$, then the decision is $\mathrm{H}_{0}$ accepted and $\mathrm{H}_{1}$ rejected, which means that Information Quality $\left(\mathrm{X}_{2}\right)$ has a positive but not significant effect toward Business Performance $\left(\mathrm{Y}_{1}\right)$. The results of the descriptive statistical test show that the Information quality variable which consists of 5 items has an average value of 3.17 while the Business performance variable consisting of 8 items gets an average value of 2.71 . This value illustrates that Information Quality practices that occur between farmers and suppliers of facilities for agricultural products, seeds, fertilizers and pesticides in the supply chain of shallots in 4 districts, namely Nganjuk, Kediri, Probolinggo and Malang are included in the good category. While the business performance variable is considered sufficient in the shallot supply chain in the 4 districts. Based on the statistical calculation test performed shows the results that the Information Quality variable has no significant effect on the Business performance variable.

The results of this study do not support the research conducted by Sundram, et al. (2015) and Gandhi, et al. (2017). This study also does not support the results of Soo Wook Kim's (2006) study which shows that there is a significant relationship between Information quality and Business Performance, with the conclusion that if an organization applies the characteristics or components in information quality then the overall performance of an organization will increase. Supported by Mwale's research, Hilda (2014) with results that also significantly influence the quality of information toward organizational performance.

Information Quality used by shallot farmers in 4 East Java districts namely Probolinggo, Nganjuk, Kediri and Malang has a low value in terms of facilities and infrastructure in terms of information exchange between farmers and trading partners, with an average value accounting for only 2.59 can be interpreted quite well. this reinforces how an Information Quality practice carried out by the supply chain elements involved has not been able to fulfill the basics of achieving good Information quality practices. Infrastructure and facilities are basic things that must exist so that the fulfillment of information needs that are of high quality and able to meet the Information Quality criteria include Accurate of Information must be free from errors and not misleading. Accurate also means that information must clearly reflect the intent. Time Lines Information that comes to the recipient may not be too late. Outdated information does not have value anymore, because information is a basis in making a decision where if the decision is too late it will be fatal for the organization. Relevant or reliable, the information has benefits for the wearer. Reliability of information for each person or element involved in the supply chain is different. 
Shallot farmers do not have enough facilities and infrastructures to exchange information with trading partners which causes the quality of information to be bad. This results in Information Quality not having a significant effect on Business performance. The difference in communication patterns carried out in each city that is the object of research also reinforces how a quality of information cannot significantly affect farmer business performance. In practice farmers in each district have a communication pattern that does not trust the information provided by trading partners and suppliers, this is related to post-harvest information that is less accurate, unreliable and not timely. So that affects the organizational decisions made. Because to improve the performance of supply chain actors, there is a need for quality information to decide on something operational, strategic and tactical. Effective sharing of information depends on what, how, and with whom the information is shared as each piece of information serves different purposes in the supply chain (Holmberg, 2000).

\section{The Effect of Integrative Supply Chains toward Business Performance}

The path analysis results prove a positive and significant influence between Integrative Supply Chains $\left(\mathrm{Y}_{1}\right)$ and Business Performance $\left(\mathrm{Y}_{2}\right)$. Obtained a beta coefficient of 0.557 means that the influence of Integrative Supply Chain $\left(\mathrm{Y}_{1}\right)$ toward Business Performance $\left(\mathrm{Y}_{2}\right)$ has a positive direction, with a tcount of 8.333 and a probability of $0.000(\mathrm{p}<0.05)$, then the decision is $\mathrm{H}_{1}$ accepted and $\mathrm{H}_{0}$ rejected, which means that the higher the Integrative Supply Chain $\left(\mathrm{Y}_{1}\right)$ will improve Business Performance $\left(\mathrm{Y}_{2}\right)$ and vice versa if the lower the Integrative Supply Chain $\left(\mathrm{Y}_{1}\right)$ will reduce Business Performance $\left(\mathrm{Y}_{2}\right)$. The results of this study support the results of the study of Liu, et al. (2013), Huo, et al. (2014), Huo (2012) which states that Integrative Supply Chain $\left(\mathrm{Y}_{1}\right)$ has a positive and significant effect on improving Business Performance $\left(\mathrm{Y}_{2}\right)$.

This study supports the statement of Vickery, et al. (2003) in Huo, (2012) "The main motivation of an integrative supply chain for most supply chain partners is to strive for superior business performance through adjusting customer needs with materials and information along the supply chain. Wong, et al. (1999) suggest that achieving superior excellence and at the same time achieving sustainable profitability requires supply chain management that is closely related to internal or external integration (Wong, et al. 1999). According to Indrajit and Djokopranoto (2002) by integrating the relationships of supply chain actors it will provide several benefits, namely adding product value, improving market access, strengthening operations, facilitating business growth, increasing organizational skills, and building financial strength. Integration and collaboration will improve business performance (Green, et al. 2006).

Based on the length of the supply chain on the shallot trade system in Nganjuk, Kediri, Malang and Probolinggo districts, it makes integrative supply chains an important strategy to do in the shallot supply chain. With the existence of good cooperation between all parties involved in the shallot supply chain, it will improve business performance both directly and indirectly. The size of the shallot farmers' income depends on the productivity and selling price of shallots. The productivity of shallots is influenced by the season, during the rainy season the maintenance costs are quite high because of many pest attacks (caterpillars) that damage the plants. While the selling price of shallots is strongly influenced by the small or large availability of shallots. Generally, the price of shallots

Vol. 28, No. 2 August 2020

(C) Centre for Indonesian Accounting and Management Research Postgraduate Program, Brawijaya University 
will drop during the harvest season or the number of imported shallots that are traded. Therefore it is necessary to have good cooperation between the members of the onion supply chain.

Relationships that are built between farmers and work partners can also influence the increase in the quantity and quality of crops so that they simultaneously improve business performance which can be seen from increasing farmers' profits. This can be seen from the collaboration between farmers, suppliers, traders in Nganjuk, Malang, Kediri and Probolinggo Regencies in monitoring the planting and harvesting processes, together increasing the production of shallots is sufficiently categorized. Unfortunately, with the increase in quantity, quality of production and profits produced by shallot farmers after cooperating with trading partners, it is considered sufficient, it can be concluded that the integrative supply chain that exists affects the business performance of shallot farmers. The higher the integrative supply chain that is established, the higher the farmer's business performance. Working partners also always hold regular technical training or regular meetings in the shade of farmer groups or a combination of farmer groups. Poktan also helps farmers to get business certification (farmer sign cards) this makes it easier for farmers to get subsidized fertilizer. Collaboration and collaboration are formed that make it very easy for farmers to carry out their operational activities.

\section{Indirect Effects of Information Sharing toward Business Performance through Integrative Supply Chains}

The results of data analysis conducted using the help of SPSS software indicate that there is a significant indirect effect between Information Sharing variables toward business performance through an integrative supply chain. The results of the coefficient value are positive so it can be concluded that if the shallot supply chain business actor implements Information Sharing, it will increase cooperation, collaboration and the creation of integrity from the members of the supply chain. A good integrative supply chain will improve its business performance. Shallot farmers carry out Information Sharing activities with facilities for agricultural products suppliers and trading partners which of course will trigger mutually beneficial cooperation in strategic decision making. Information Sharing activities carried out will enhance collaboration and collaboration that are mutually beneficial. The existence of cooperation will increase integration so that the flow of funds, the flow of information and the flow of goods will be well managed so that the performance of the supply chain will increase. To find out that there is an indirect relationship between Information Sharing and business performance through the integrative supply chain are as follows:

1. Information Sharing variable path coefficient value for integrative supply chain is 0.383

2. The path coefficient value of the integrative supply chain variable on business performance is 0.557

3. Information Sharing variable path coefficient value for business performance through an integrative supply chain of 0.213 . And the total effect is 0.426

4. Sobel value test 4,441 with $P$ value 0,000 or significant

Vol. 28, No. 2 August 2020

(C) Centre for Indonesian Accounting and Management Research Postgraduate Program, Brawijaya University 
Based on the path coefficients above, Information Sharing's indirect influence on supply chain performance is 0.213 . This supports the study of Sundram, et al. (2015) which proves that there is a positive and significant relationship between Information Sharing and Business performance through an integrative supply chain. Business people who implement supply chain management practices including information sharing will improve their business performance both directly and indirectly. Having good integration with suppliers will improve supply chain performance in cost savings and reliability.

\title{
Indirect Effects of Information Quality toward Business Performance through Integrative Supply Chains
}

The results of data analysis carried out using the help of SPSS software indicate that there is an insignificant indirect effect between Information Quality variables on business performance through an integrative supply chain. The results of the coefficient value are positive so it can be concluded that if the actors of the onion trading system implement Information Sharing, it will increase collaboration, collaboration and the creation of integrity from the members of the supply chain. A good integrative supply chain will improve the performance of the business. Shallot farmers who implement Information Quality well and in the long term will make the partnership relationship will enhance collaboration and collaboration that are mutually beneficial. To find out that there is an indirect relationship between Information Quality and the supply chain performance through integrative supply chains are as follows:

1. Information Quality variable path coefficient value for integrative supply chain is 0.023

2. The path coefficient value of the integrative supply chain variable on business performance is 0.075

3. Information Quality variable path coefficient value for supply chain performance through an integrative supply chain is 0.012 . And the total effect is 0.024

4. The Sobel test value is 0.308 with $P$ value 0.757 or insignificant

Based on the path coefficient above, the indirect effect of Information Quality on business performance is 0.024. This supports the study by Sundram, et al. (2015). These results support the Gandhi, et al. (2017) shows a positive and significant relationship both directly and indirectly between supply chain management practices, one of which is Information quality has a relationship with suppliers and business performance. A good relationship between business actors and suppliers considered to be able to improve and enhance business performance either directly or indirectly through an integrative supply chain and supply chain performance that is created.

\section{CONCLUSIONS AND SUGGESTIONS CONCLUSIONS}

Based on the results of the research and discussion described in the previous chapter, the conclusions of this study are as follows:

1. The results of testing hypothesis 1 indicate that the Information Sharing variable $\left(\mathrm{X}_{1}\right)$ has a positive and significant influence toward the Integrative Supply Chain $\left(\mathrm{Y}_{1}\right)$. The results of the Path analysis show that the effect of the Strategic Information Sharing $\left(\mathrm{X}_{1}\right)$ toward Integrative Supply Chains $\left(\mathrm{Y}_{1}\right)$ is 0.383 .

\author{
Vol. 28, No. 2 August 2020 \\ (C) Centre for Indonesian Accounting and Management Research \\ Postgraduate Program, Brawijaya University
}


2. The results of testing hypothesis 2 indicate that the information sharing variable $\left(\mathrm{X}_{1}\right)$ has a positive and significant influence toward Business Performance $\left(\mathrm{Y}_{2}\right)$. The results of the Path analysis show that the effect of Information Sharing $\left(\mathrm{X}_{1}\right)$ toward Business Performance $\left(\mathrm{Y}_{2}\right)$ is 0.139 .

3. The results of testing hypothesis 3 indicate that the Information Quality $\left(\mathrm{X}_{2}\right)$ variable has a not significant positive effect toward the Integrative Supply Chain $\left(\mathrm{Y}_{1}\right)$. The results of the Path analysis show that the effect of Information Quality $\left(\mathrm{X}_{2}\right)$ toward Integrative Supply Chains $\left(\mathrm{Y}_{1}\right)$ is 0.023 .

4. The results of testing hypothesis 4 indicate that the Information Quality $\left(\mathrm{X}_{2}\right)$ variable has a non-significant positive influence toward Business Performance $\left(\mathrm{Y}_{2}\right)$. The results of the Path analysis show that the effect of Information Quality $\left(\mathrm{X}_{2}\right)$ toward Business Performance $\left(\mathrm{Y}_{2}\right)$ is 0.075 .

5. The results of testing hypothesis 5 indicate that the Integrative Supply Chain variable $\left(\mathrm{Y}_{1}\right)$ has a positive and significant influence toward Business Performance $\left(\mathrm{Y}_{2}\right)$. The results of the Path analysis show that the effect of Integrative Supply Chain $\left(\mathrm{Y}_{1}\right)$ toward Business Performance $\left(\mathrm{Y}_{2}\right)$ is 0.557 .

6. The results of testing hypothesis 6 indicate the indirect effect of Information Sharing $\left(\mathrm{X}_{1}\right)$ toward business performance $\left(\mathrm{Y}_{2}\right)$ through an integrative supply chain $\left(\mathrm{Y}_{1}\right)$. Based on the results of data analysis that has been carried out obtained indirect path coefficient of 0.426 .

7. The results of testing hypothesis 7 show the indirect effect of Information quality $\left(\mathrm{X}_{2}\right)$ toward business performance $\left(\mathrm{Y}_{2}\right)$ through an integrative supply chain $\left(\mathrm{Y}_{1}\right)$ of 0.024 .

\section{SUGGESTIONS}

1. For perpetrators of shallot trade system should increase cooperation or integration among farmers, suppliers, collectors and traders because to be able to produce shallot which is needed, superior seeds are also needed, drugs or fertilizers are also important for shallots to avoid pests that can causing crop failure, relationships with good customers can determine the selling price of shallots. With the establishment of good relations between suppliers, farmers, and customers, it can also improve the integration of supply chains as well so as to improve farmer business performance.

2. For the perpetrators of the shallot trading system, it is hoped that it can better implement supply chain management to overcome the problems that occur in the shallot trading system. optimize supply chain management by practicing supply chain management activities, one of which is Information Sharing and Information Quality. Shallot farmers can conduct partnerships through institutions such as Gapoktan or Poktan in partnership with union or build partnerships for operational cooperation in agribusiness to obtain financing, capital, management and procurement of agricultural production facilities.

3. For further researchers, it is expected to add other variables which are included in the supply chain management activity component as a good supply chain management activity. postponement, agreed vision and goals etc. as additional variables to support analysis. 
4. For further research, it is expected to be able to examine with a wider sample and analyze based on the area of each shallot production center because there are different characteristics of the shallot trade system in each center region.

5. The object of research in this study was only carried out on shallot farmers, so that the next researcher is expected to be able to examine not only farmers but also to suppliers of drugs, seeds, facilities for agricultural products and collectors, traders so that the information obtained is wider. 


\section{REFERENCES}

\section{Book}

Assauri, Sofjan (2011), "Strategic Management, Sustainable Competitive Advantages", Lembaga Management Fakultas Ekonomi Universitas Indonesia, Jakarta.

Chopra, S. \& Meindl, P. (2013). Supply Chain Management: Strategy, Planning, and Operations, 5rded. New Jersey: Prentice-Hall.

Christopher, M. 1992. Logistic and Supply Chain Management, London: Pitnam Publishing

Cooper, D.R., dan Emory, C.W. 1995. Business Research Methods. New York: McGraw Hill.

Darmawan, Deni. 2014. Metode Penelitian Kuantitatif. Cetakan ke 2.Bandung : PT Remaja Rosdakarya.

Handfield, Robert B., Nichols, Ernest L. (1999). Introduction to supply chain management. Prentice Hall, Singapura.

Heizer, Jay dan Barry Render. 2015. Operations Management: Sustainability and Supply Chain Management. Terjemahan. Jakarta: Salemba Empat.

Indrajit, R.E dan R. Djokopranoto. (2002), Konsep Manajemen supply Chain. PT Grasindo, Jakarta.

Jacobs, F. Robert dan Richard. B. C. 2015. Operations and Supply Chain Management. Terjemahan. Jakarta: Salemba Empat.

Kuncoro, M. 2003. Metode Riset untuk Bisnis dan Ekonomi. Jakarta: Erlangga.

Nazir, Mohammad.2014. Metode Penelitian Bisnis. Bogor : Ghalia Indo

Richey, R.C \& Klein J.D. 2007. Design and Development Research Methods, Strategies, and. Issues. New Jersey: Lawrence Erlbaum Associates.

Prastowo, B., et al., 2010, Budidaya dan Pasca Panen bawang Nitro PDF, Hal 1

Pujawan, I Nyoman.2005. Supply Chain Management, Edisi Pertama. Guna Widya, Surabaya.

Putrasamedja, Sartono dan Suwandi. 1996. Varietas Bawang Merah di Indonesia. Bandung: Balai Penelitian Tanaman dan Sayuran.

Sekaran, Uma, and Bougie, R. 2013. "Research Methods for Business." In Research Methods for Business, 436.

Stevenson, William J dan Chuong. Operations Management: An Asian Perspective.Terjemahan. Jakarta: Salemba Empat.

Sarwono, Jonathan. 2007. Analisis Jalur untuk Riset Bisnis dengan SPSS. Yogyakarta: Andi Offset.

Sugiyono. 2007. Statistika Untuk Penelitian. Bandung: Alfabeta

Sugiyono. 2011. Metode Penelitian Kuantitatif Kualitatif dan R\&D. Bandung.

\section{Journal}

Agus, Arawati. 2011. "The Significant Effect of Information Sharing and Strategic Supplier Partnership on Supplier Performance" International Journal of Business and Management Science 4 (1), 75-92. 
Agus ,Arawati and Hassan, Za'faran.(2008). “The Strategic Supplier Partnership in a Supply Chain Management with Quality and Business Performance" International Journal of Business and Management Science, 1(2): 129-145.

Anderson, K.E. 2016. "Getting Acquainted with Social Networks and Apps: Picking up the Slack in Communication and Collaboration." Library Hi Tech News 33 (9):6-9.

Al-Shboul, M. A., Barber, K., Garza-Reyes, J. A., Kumar, V., and Abdi, M. (2017). "The effect of supply chain management practices on supply chain and manufacturing firms' performance, Journal of Manufacturing Technology Management, Vol. 28 No. 5,pp. 577-609.

Barth, Mary E., et al. 2008. International Accounting Standards and accounting quality. Journal of Accounting Research, 46(3): 467-498.

Chopra, Sunil and Peter Meindl. (2004). "Supply Chain Management: Strategy, Planning, and Operations”. Second Edition, Prentice Hall Inc., Upper Saddle River, New Jersey.

Cooper, Martha C., Douglas M. Lambert, and Janus D. Pagh, (1997), "Supply Chain Management: More than a New Name for Logistic", The International Journal of Logistics Management, Vol. 8 No. 1, 1-14

Dong, S., Xu, S.X., and Zhu, K.X. (2009). Information Technology in Supply Chains: The Value of IT-Enabled Resources Under Competition. Information Technology in Supply Chains Information Systems Research. 20(1), 18-32.

Gandhi, A.V., Ateeque Shaikh, Pratima Amol Sheorey. 2017.Impact of supply chain management practices on firm performance: Empirical evidence from a developing country", International Journal of Retail \& Distribution Management, Vol. 45 Issue: 4, pp.366-384.

Gunasekaran A, Patel C, and Tirtiroglu, E. (2001). "Performance measures and metrics in a supply chain environment, International Journal of Operations and Production Management;21(1/2):71-87.

Huo, B. 2012. The impact of supply chain integration on company performance: an organizational capability perspective. Supply Chain Management: An International Journal, 596-610.

Huo, B., Qi, Y., Wang, Z., \& Zhao, X. 2014. The impact of supply chain integration on firm performance The moderating role of competitive strategy. Supply Chain Management: An International Journal, 369-384.

Heizer, Jay., \& Render, Barry. (2008). Manajemen Operasi. Jakarta: Salemba Empat.

Huo, B. (2012). "The impact of supply chain integration on company performance: an organizational capability perspective, Supply Chain Management: An International Journal, 596-610.

Huo, B., Qi, Y., Wang, Z., and Zhao, X. (2014). "The impact of supply chain integration on firm performance The moderating role of competitive strategy, Supply Chain Management: An International Journal, 369-384.

Kim, So W. 2009.Quality Management Strategy in Supply Chain for Performance Improvement. Asian Journal on Quality, Vol. 10 Issue: 3, pp.43-64.

Kim, S.W. (2006). Effects of supply chain management practices, integration and competition capability on performance. Supply Chain Management: An 
International Journal, $11(3), \quad 241-248 . \quad$ DOI= http://dx.doi.org10.1108/13598540610662149

Liu, H. 1994. "Market orientation and firm size: An empirical examination in UK firms". Eur. J. Mark, 29(1): 57-71.

Lee, H. L., (2000). "Creating Value through Supply Chain Integration”, Supply Chain Management Review Vol 4 No 4 pp 30-36.

Lee, H. L. and S. Whang, (2000), "Information Sharing in a Supply Chain", International Journal of Technology Management, Vol. 20 No. 3/4 pp. 373- 387

Lee, H. L. Padmanabhan, V., dan Whang, S. 1997. "The Bullwhip Effect In Supply Chains." Sloan Management Review, Spring: 93-102.

Mwale, H. (2014). Supply Chain Management Practices And Organizational Performance Of Large Manufacturing Firms In Nairobi, Kenya. Tesis , Business Administration School of Business University of Nairobi.

Mentzer et al. 2001. "Defining Supply Cahin Management." Journal of Business Logistics, Vol. 22, No. 2.

Moberg, C. R., Cutler, B. D., Gross, A. \& Speh, T. W. (2002). Identifying Antecedents ofInformation Exchange Within Supply Chains. International Journal of Physical Distribution\& Logistics Management, 32(9), 755-770.

Narasimhan, R. \& Kim, S. W. (2002). Effect of Supply Chain Integration on The RelationshipBetween Diversification and Performance: Evidence From Japanese and Korean Firms.Journal of Operations Management, 20, 303-323

Raisinghani, M.S. and Meade, L.L. 2005. "Strategic Decisions in Supply-chain Intelligence Using Knowledge Management: An Analytic-network-process Framework." Supply Chain Management: An International Journal 10 (2):11421.

Robinson, C. and Malhotra, M.K. (2005). "Defining the concept of supply chain quality management and its relevance to academic and industrial practice, International Journal of Production Economics, 96(1): 315-337.

Shidharan., R dan Simatupang, T.M., (2009), "Managerial views of supply chain Collaboration", Gadjah Mada International Journal of business, MayAugust 2009 Vol 11-No.2, pp253-273)

Simpson, D., Power, D., dan Samson, D. 2007. “Greening the automotive supply chain: a relationship perspective." International Journal of Operations \& Production Management, Vol. 27, No. 1, pp 28-48.

Singh, P. J., and Power, D. (2009). "The nature and effectiveness of collaboration between firms, their customers and suppliers: a supply chain perspective, Supply Chain Management: An International Journal, 189-200.

Sezen, B. (2008). "Relative effects of design, integration and information sharing on supply chain performance". Supply Chain Management: An International Journal, 233-240.

Sundram, V. P. K., Ibrahim, A. R., \& Govindaraju, V. G. R. C. (2011). Supply Chain ManagementPractices in the Electronics Industry in Malaysia. Benchmarking: An International Journal,18(6), 834-855.

Zhou H. \& Benton, W. C. Jr. (2007). Supply Chain Practice and Information Sharing.Journal of Operations Management, 25, 1348-1365.

Vol. 28, No. 2 August 2020

(C) Centre for Indonesian Accounting and Management Research Postgraduate Program, Brawijaya University 
Zhao, X., Xie, J., \& Zhang, W. J. (2002). The Impact of Information Sharing and Ordering Co-ordination on Supply Chain Performance. Supply Chain Management: An InternationalJournal, 7(1), 24-40.

Narasimhan, R. \& Kim, S. W. (2002). Effect of Supply Chain Integration on The RelationshipBetween Diversification and Performance: Evidence From Japanese and Korean Firms.Journal of Operations Management, 20, 303-323

Lee, H.L., So, K.C., \& Tang, C.S. (2000). The value of information sharing in a two-level supply chain, Management Science, 626-643.

Li, S., Ragu-Nathan, B., Ragu-Nathan, T., \& Subba Rao, S. (2006). The impact of supply chain management practices on competitive advantageand organizational performance. Omega. 34(2), 107-124. DOI= http://dx.doi.org10.1016/j.omega.2004.08.002

Li, S., Subba Rao, S., Ragu-Nathan, T.S., \& Ragu-Nathan, B. (2005). Development and validation of a measurement instrument for studying supply chain management practices. Journal of Operations Management. 23(6), 618-641. DOI= http://dx.doi.org/10.1016/j.jom.2005.01.002

\section{Internet}

www.bps.co.id

www.kemendag.co.id

www.Forbes.com 